\title{
Justyna Górny
}

Institute of German Studies, University of Warsaw (Poland)

\section{THE IMAGE OF EDUCATED WOMEN IN TWO INTERWAR AUSTRIAN NOVELS BY FEMALE AUTHORS}

\begin{abstract}
The article sketches a portrayal of educated women in literature of the interwar period. The ways are shown in which typical experiences of women students are reflected in prose works describing the consecutive stages of scholarly career - from the beginning of one's university studies to successful independent work. The figure of female student and scientist is shown in the novels concerned as a model example of emancipation, while the influence of a conservative concept of femininity is apparent. The model protagonist is a utopian figure as it harmoniously merges emancipative and conservative elements.
\end{abstract}

Keywords: Grete von Urbanitzky, Vicki Baum, Austrian interwar fiction, female student in literature (prose fiction)

\section{I \\ INTRODUCTION}

Educated woman as a literary motif was no more a novelty in the Interbellum period. German-language novels with students as characters first appeared in the late nineteenth century. In her analysis of these pieces, Romana Weiershausen finds that the female student character, which in the late nineteenth/early twentieth century became a new field of literary exploration, was not a neutral motif at the time but functioned, instead, as a peculiar provocation: a type of figure with an imminent 'critical potential'. "The texts to which a studying woman is central, have a certain inherent critical potential, regardless of their political orientation. The critique starts with the figure of the student and concerns the concrete situation of women. ... In progressive works ... as well as in conservative-oriented novel ... hope is placed in woman". ${ }^{1}$

${ }^{1}$ Romana Weiershausen, Wissenschaft und Weiblichkeit. Die Studentin in der Literatur der Jahrhundertwende (Göttingen, 2004), 95-7. 
Novels about women students would thence make subject to critical revision certain aspects of social life while showing female characters as 'prime movers'. Yet, Weiershausen has confined this perspective by pointing out that although authors (female and male) writing on women students presented 'counter-discourses' in their novels to oppose the system being criticised, what they de facto did was to reinforce and strengthen what they criticised (presentation of socialism, nihilism, or feminism with use of a background figure, whilst rejection of such views by the central character, could serve as an example). Two novels from the 1920s/1930s: Vicki Baum's stud. chem. Helene Willfüer $(1929)^{2}$ and Grete von Urbanitzky's Eine Frau erlebt die Welt (1931) ${ }^{3}$ seem to have joined the trend. Both texts display a 'critical potential', chiefly stemming from the portrayal of the respective protagonists Helene in Baum's novel and Mara in Urbanitzky's - as emancipated women, outright shining examples of woman's independence. In both novels, we trace the vicissitudes of the female character from her young (or childhood) years to her adulthood; both women are students, emancipated and independent also in the sexual sphere; they resolve to go for extramarital maternity, embark on a successful scholarly career. Their biographies are completely individual projects, never subjected to limitations imposed by the gender roles, or even social position. The radicalism of these biographies is assuaged, though, for both characters concerned have been excluded from the emancipation discourse: economic independence, sexual freedom, access to education, intellectual attainments are not achievements of female rebellion, something women had fought their way to get - but rather, an obvious thing, a possibility that indisputably exists and whose use is unchallenged. Moreover, as I will show below, the novels contain threads strongly anchored in conservative, or even nationalist, discourses. ${ }^{4}$ With this kept in mind, one may claim that

${ }^{2}$ Vicki Baum, stud. chem. Helene Willfüer (Munich, 1983; Berlin, 192811).

${ }^{3}$ Grete von Urbanitzky, Eine Frau erlebt die Welt (Berlin et al., 1937), 1931'; quoted herein as Eine Frau (1931) and Eine Frau (1937).

${ }^{4}$ It is purposeful that I set the emancipative discourse against the conservative or nationalist discourse. True, there appeared initiatives of conservative-oriented women, which, due to the peculiar context of their activities, might be regarded as a form of emancipation (for instance, charity actions of female landowners, women's religious organisations), but as far as literary fiction of the period is concerned, there is a clear difference between emancipative-liberal or left(ist)-oriented novels, 
the two texts under discussion, being novels on female students, are marked with a 'critical potential' which grows tampered. In both, what we deal with is balancing between a radical picture of female emancipation and a conservative or traditional discourse. Urbanitzky's novel is the explicit example: the author altered its conclusion, thus inhibiting the emancipation drive of the text she had penned and, downright, altering its meaning. By removing the final chapter in the subsequent editions, the author erased a futuristic fantasy set in the 1950s, where the central character turns into a matriarchal founder of a new religion. ${ }^{5}$ The conclusion of the penultimate chapter, which has functioned as the conclusion of the whole novel since its second edition, is open-ended: the main character disappears, possibly committing suicide. Thus, the author has amputated the radical purport of her text, in a pretty literal manner.

II

HELENE, AN IRON-WILLED GERMAN WOMAN STUDENT

The aforesaid two novels have been selected for analysis as educated women are their main figures, their life stories forming the plot's structural axis. Both authors were renowned women-of-letters in the Interbellum period. A very popular author, Vicki (born Hedwig) Baum (1888-1960) cooperated with the renowned Berlin-based Ullstein publishers. Since the early thirties she wrote scripts for Hollywood

on the one hand, and those with a conservative purport, on the other. It needs also to be remarked that if female conservative fiction-writing authors operated in the public space, thus breaking the traditional role of woman, this not necessary translated into their prose works. In the novels of Urbanitzky and Baum it is fairly clear that emancipation is understood in a progressive way, which becomes even more distinct when comparing the main characters with unambiguously conservative concepts - such as the female character of Brigitte Lossen's novel Mutterseele, whose love for her husband finally adds meaning to her existence; driven by affection, she kisses his hands, kneeling at his chair (yes, indeed!). The only manifestation of emancipation in this character is her autonomous decision of parting with her career as an artist and living entirely for her husband and child ever since. Urbanitzky and Baum refer to emancipation discourse comprehended in a completely different - namely, liberal and progressive - way.

${ }^{5}$ These alterations have been pointed out by Ursula Huber, 'Die Frau als "Künstlerin”. "Klugrednerei?" Fragen der weiblichen Identität und Macht in einigen Romanen Grete von Urbanitzkys', Zeitgeschichte, xvi, 11/12 (1989), 390-1. 
studios. In 1932 she and her family moved to the United States and in 1938 Baum received the U.S. nationality. ${ }^{6}$ Her texts were classified in the interwar years as popular literature, a view which is generally shared by today's literary scholars. The same would basically be true of the novel under analysis: while containing thrilling elements, it bears signs of an optimistic fable for adults, both plot-wise and in terms of construction. ${ }^{7}$ However, Baum's prose works are worthy of note because they were so widely read and sparked lively discussions in public space. As an author, Vicki Baum tends to be analysed as a peculiar mass-media phenomenon: subject to study have been, for instance, the strategies of Ullstein which contributed to the novel's success among the reading public. ${ }^{8}$ One such strategy was the author's (self-) stylisation as a 'New Woman'. Following the relevant analyses, I understand this term as a tool helping to grasp the real novel opportunities that opened to women in post-First World War Germany, as well as in terms of a media creation, a product of illustrated magazines and fashion industry. ${ }^{9}$ Indeed, Vicki Baum's fiction prose works and

${ }^{6}$ Nicole Nottelmann, Strategien des Erfolgs. Narratologische Analysen exemplarischer Romane Vicki Baums (Würzburg, 2002), 40-1.

7 Ibidem, 95. Nottelmann discerns in Baum's novel structural elements of 'development novel' (Entwicklungsroman), romance novel, fable, 'judiciary novel' (Justizroman), and 'science novel' (Wissenschaftsroman).

${ }^{8}$ Ibidem, 60-82.

${ }^{9}$ For interpretation of the 'New Woman', see Petra Bock, 'Zwischen den ZeitenNeue Frauen und die Weimarer Republik', in eadem and Katja Koblitz (eds.), Neue Frauen zwischen den Zeiten (Berlin, 1955), 15-37; esp. 14-15. Petra Bock proposes that 'New Woman' be differentiated into the mass-replicated media image and the actual 'type' of emancipated woman that really existed in the social reality. Julia Bertschik, for a change, opts for the concept of 'New Woman' - as proposed by Katharina Sykora - as a 'myth of everydayness', for such a methodological approach would enable to describe a "dialectics of fashion-and-media-dictated objectification and opening of new spaces of activity", as characteristic of the 'New Woman'. The latter proposition seems convincing; in any case, it is seemingly useful in showing the duality of the phenomenon that functions at the intersection of everyday realities and commercial media-attraction quality. See Julia Bertschik, 'Vicki Baum: Gelebter und inszenierter Typ der Neuen Frau', in Waltraud Wende (ed.), Nora verläßt ihr Puppenheim. Autorinnen des zwanzigsten Jahrhunderts und ihr Beitrag zur ästhetischen Innovation (Stuttgart and Weimar, 2000), 66-87; esp. 69-70. Nicole Nottelmann, Strategien des Erfolgs; eadem, Die Karrieren der Vicki Baum. Eine Biographie (Köln, 2007); Julia Bertschik, "'Ihr Name war ein Begriff wie Melissengeist oder Leibnizkekse". Vicki Baum und der Berliner Ullstein-Verlag', in Walther Fähnders and Helga Karrenbrock (eds.), Autorinnen der Weimarer Republik (Bielefeld, 2003), 119-35. 
journalism were usually accompanied by a meticulously stylised media image: the publisher offered the readers a peculiar package composed of the author and her text. In parallel, Baum's success among readers was too remarkable to make marketing strategies chiefly responsible for it. stud. chem. Helene Willfüer was first issued as a serial novel, published from 1928 onwards by the Berliner Illustrierte Zeitung. The popularity of the novel is attested by hundreds of letters received by the editorial board and by the magazine's circulation increase of 200,000 copies. 1928 also saw the Baum novel issued in a book form, selling 105,000 copies within eighteen months. ${ }^{10}$

The reader meets the protagonist, Helene Willfüer, at the moment she begins her tertiary studies, opposing her family's will. A fledgeling chemistry student, she sums up her family disputes saying, "But I did get it all my own way". ${ }^{11}$ At the laboratory, Helene is passed into custody of Professor Ambrosius, a renowned specialist whom she considers her excellent mentor. Thus, initially things go according to plan, at least until the student gets pregnant as a result of a single moment of lapse, or distraction, in her disciplined and regulated course of life. This is how her extramarital pregnancy is shown a consequence of a temporary break in self-control. Moreover, Helene is seduced not so much by a man as by the circumstances: a hot eventful night in May, a spontaneous knees-up, jazz music played by an exotic, somewhat demonic, black-skinned painter from Paris (of whom more will be said hereafter), unrestrained behaviour of the other couples are all elements of the scenery. The father of the conceived child is a medicine student named Fritz Rainer. After a few failed attempts at carrying out the abortion on her own or undergoing surgery, Helene confesses to her beloved one that she is expecting a baby. ${ }^{12}$ None of the two feels strong enough to face the problems

${ }^{10}$ Nottelmann, Die Karrieren der Vicki Baum, 125-6.

11 Baum, Helene, 5-6.

12 I will omit the thread of would-be abortion as it does not strictly relate to the present topic, however I must at least mention it since its significance for immediate reception of this novel was great. Helene embarks on an 'abortion pilgrimage' of sorts: she tries out all the existing options, to no avail; as she ascertains, had she had access to appropriate measures, she would have had no problem doing what she intended to do (in spite of the formal ban), whereas a poor woman could have only resorted to some pseudo-medical procedures posing a threat to her health or life. Vicki Baum thereby joined the critiques of the restrictive antiabortion laws then 
related to the situation, and they finally decide to commit suicide together. Helene quits the idea just before this is about to happen, but is accused of having killed Rainer instead. Although she is exonerated in the investigation, the out-of-wedlock pregnancy and the resulting scandal force the girl to quit her Heidelberg studies and move to the Munich university. This loosens her relationship with Professor Ambrosius, without completely severing it; Helene thinks of his tutor with nostalgia: "what a man was that, what a teacher, oh how much he mattered to me, and to all of us!". ${ }^{13}$ Apart from replacement of tutor, Helene has to tackle several other problems. She wrestles with poverty, which is all the more dramatic that she is awaiting a child. A severe blow for her is the need to alter the topic of her thesis: "Now I have to quit everything I have done around my succinic acid azides: all those small and nice results it had been so tough to attain ... This time, synthesis of pyrazole derivatives is the case, and Heaven help me so I can move forth with this, somehow". ${ }^{14}$ She thus has to quit the subject she has been working on with confidence, and embark instead on an issue she actually finds unappealing. At this point, it is no more about her passion for studying chemistry but, completely pragmatically, about completing her graduation in spite of adversities. One problem Helene describes in letters to her friend is the expected response of her colleagues: "You know the student tribe, my dear Kranich; you know that a woman student with a child makes a nonsense, and perhaps you can figure how I am treated by everyone around here, a professor or caretaker. So far, I could stand it, and this is what counts". ${ }^{15}$ Helene's most painful experience comes from a student named Bodrum, whom she describes thus: "Corporation, beer, graduated cylinder, adventures told very loudly - not always pleasant to listen to". ${ }^{16}$ It is because of this particular student that Helene almost gets removed from the laboratory. Bodrum indulges in vulgar commentaries targeted at his female mate who, in an attempt to avoid fuss, tries hard not to reveal how shocked and how offended she was. Meanwhile, Helene's other colleague, Morgenbloom, stands

in force in Germany - and this is how her text was read at the time, generating approval as well as criticism.

\footnotetext{
${ }^{13}$ Baum, Helene, 132.

${ }^{14}$ Ibidem, 128.

${ }^{15} \mathrm{Ibidem}$.

${ }^{16}$ Ibidem, 129.
} 
up for her, and the chemical laboratory is shaken by a moral scandal. The man in charge of research practiced by students, Privy Councillor Brockhaus, initially wants Helene - the controversy's propeller - to leave the laboratory and only return after the delivery, or, as he puts it, "Once the whole bloody mess ends up". ${ }^{17}$ However, when Helene tells him about the condition she lives in and the adversities she has to wrestle when studying, Brockhaus changes his mind and decides to support her. His attitude is critical for Helene's position in the student group: "when he controls my work, there is complete silence, all the nearby tables grow standstill, watching the professor and me ... then, the Privy Councillor said very loudly, pointing at me with his crooked finger: "Humph. Your labour will become a thing! Ahem. Respectful! Miss Willfüer!"18 This scene shows an essential aspect in the relationship between the student and her tutor: even if Brockhaus is not the mentor for her - for Ambrosius constantly is the one - his approval is nonetheless the indispensable source of legitimisation, as if the matriculation in itself had not been enough to justify Helene's presence in the laboratory. Establishing an understanding with the superior is also an essential condition for surviving in the indifferently inimical peer environment. Baum's character does not fit within traditional academic structures: not only her membership in the corporation would have been unconceivable, but even ordinary relationships with her colleague students are inaccessible to her. Taking the above description into account, it would be hardly thinkable that, for instance, someone of the students is helping her conceal some minor deficiency at the laboratory at the last minute before Brockhaus comes up to do his inspection. Helene's only mate, the one who protested when she was being insulted, is an outsider too: "a little assiduous man he; his name is Morgenbloom. A being shrunk inside himself, intimidated, his teeth rotten and his eyes observant, all covered with pimples. He looks as if he all consisted of suppressed complexes. ... We have a word with each other at times; poor souls we". ${ }^{19}$ In spite of the disheartening picture of estrangement of a young woman who can only make contact with another excluded individual, the Baum text may be considered as a perverse testimony of a positive mentality change. Should we

\footnotetext{
17 Ibidem, 135.

18 Ibidem, 132,135.

19 Ibidem, 129.
} 
agree with the argument proposed by Weihershausen (as referred to above) that in the late nineteenth/early twentieth century the figure of female student was a literary provocation, then, in a late-1920s novel, the fact that a woman is a university student is, most clearly, too weak a premise to provoke. In her intention to provide a convincing argument for hostility of a university environment, the author uses a larger-calibre weaponry: the taboo is infringed by an extramaritally pregnant student.

Thanks to her extraordinary fortitude and strength of will, Helene resumes and formally completes her studies after the delivery of her baby. It is however clearly apparent in Baum's novel how essentially limited this success was. As Helene reports, "I am living in Brunsdorf now, it is a small out-of-the-way place near Hanover. There is a factory in Brunsdorf, a railway station, a doctor and a pharmacy, and that's it. There is a cellar in the pharmacy, and there in the cellar stand three cylinders with Bertrand's reagents. That's all. It is where I sit and test urine samples for the locals of Brunsdorf". ${ }^{20}$ Ambrosius, her former tutor, responds to this story: "Oh well, you could well be doing this without ever studying chemistry". ${ }^{21}$ Helene's situation is further complicated by the fact that she has an illegitimate child; she was dismissed from fairly convenient posts for this very reason. And, this was the actual cause of her main problem - namely, the boring and low-paid deskilled job she performed. Apart from Helene, the other case in point is Gudula Rapp, her once-mate from the Heidelberg lodgings. Gudula Rapp, the character present on the novel's sidelines, basically shares the lot with Helene. An archaeology student, Gudula chooses as her graduation thesis topic 'Hellenistic motifs in East Asian Buddhist art', an issue she is really fond of. However, in working on the dissertation, she comes across enormous difficulties as she cannot afford travel which is indispensable for completing an up-tothe-standard study. She repeatedly sinks into doubt, which makes her work on the 'doctoral-thesis' even harder. Since Gudula's and Helene's paths go separate ways, the reader gets to know about her further life only from two brief mentions, one being a narrative commentary: “... you are a talented human being, you do have the potential to become a coryphaeus of archaeology; but, Gudula Rapp, I do not place

\footnotetext{
20 Ibidem, 142.

21 Ibidem.
} 
much hope in you ... You will have your doctor's degree attained. But you will never excavate a fantastic town out of the sands of a desert, or lead an expedition, or travel. You will live a monotonous life amidst lifeless dust-covered objects, and will write small dust-covered articles for periodical magazines which will never be able to comprehend them. Perchance, I will meet you again some day, poring, short-sighted, over the long inventory lists, for you have been admitted to arranging and cataloguing some lower-valued collections". ${ }^{22}$ Later on, the reader merely learns that, with the graduation diploma in her pocket, Gudula leaves for Berlin in search of any paid job, not necessarily related to the course of her studies.

The novel thus shows that neither does completion of tertiary studies and final graduation stand for fulfilment of one's intellectual ambitions nor does it ensure a satisfactory career. Seen in this perspective, a graduation certificate is not a purpose in itself: rather, it ought to be a key to success, preferably scientific as well as financial. Initially, however, Helene's thoughts do not go beyond the graduation diploma. Asked what comes next, once she completes her study, she absentmindedly replies, "Next? What do you mean, 'next'? What are you talking about?". ${ }^{23}$ Contrary to its character, the novel can readily tell us more - thus creating an interesting discourse between the character and the narrative. Helene does not complain about her situation, as if she did not notice the discrimination affecting her. Instead, threads and mentions are disseminated across the narrative meant to make the reader aware that if urine sample testing or cataloguing "some lower-valued collections" comes as the effect of their studies, women may really feel disappointed. Yet, Helene's disappointment is temporary: thanks to intermediation of her former tutor, she finds a job with a private laboratory where she joins a successful investigation of a substance named Vitalin, being a synthetic hormone with revitalising properties. Helene works with a three-member team that finally produces the Vitalin after several years of work and failed experiments. It is Helene, whose contribution to the successful outcome was essential, who will in the future run the manufacture of the stimulant. At one point, she embarks on business negotiations with industry representatives and it is this particular talk, described

22 Ibidem, 99.

${ }^{23}$ Ibidem, 30. 
in detail, that becomes the actual crowning of her studies and the climax in the career of the chemistry graduate: "Doctor Willfüer came to the table to have a fundamental talk with the men who managed Germany's largest chemical factory, looking cool and distanced as if she had never done anything else". ${ }^{24}$ Helene is a hard and competent bargainer, steady and self-assured. The intellectual passion that once pushed her forth to go to a university has now led her to a success in research and career. In Vicki Baum's novel, investigation into chemical compounds not only helps expand the limits of cognition but fulfils certain quite concrete functions in the social reality. The research Helene so remarkably contributes to is not only about cognising the action of hormones but also about using the knowledge in practice, in a way beneficial to the society: Vitalin appears to be a salutary substance, able to regenerate the human organism. Professor Ambrosius is among those who make use of the preparation: psychically broken after he was left by his wife, he lost his physical health resulting from a failed suicidal attempt. Healed and rejuvenated with Vitalin, the convalescent resumes active work and can live a full life again. The novel has elements of laboratorial romanticism or, outright, kitsch to it: the discovery of Vitalin calls for enormous sacrifice, a whole decade of tireless labour, superhuman discipline and persistence. That enormous effort is required is apparent from Helene's talk with another laboratory worker, during which they exchange remarks of what stimulants they use to cope with the work (Helene uses cola, the professor is fond of cocaine, and so on). Thousands of failed attempts have not discouraged the chemists and their perseverance is awarded, at last. It is not the discovery, though - which is merely mentioned in a short paragraph - the peak of Helene's career: the real moment of glory is her meticulously described negotiations with the owners of the chemical factory. It is this particular success that truly crowns the Helene's laboratory sacrifices. Her great discovery becomes fully valuable only when it 'hits thatched houses', winning her acclaim among her milieu and commercial success.

The culmination of Helene's story as a bestselling novel's character would only need a love story to be complete. Indeed, in the final section Helene comes across Professor Ambrosius while on his holiday in Italy. At the beginning of the novel, Ambrosius looks asexually at Helene,

${ }^{24}$ Ibidem, 165-6. 
his relationship with the former charge is free of erotic significance. The great chemist is undergoing an obsessive fascination with his wife, Yvonne Pastouri, who displays a gift for music. The luxury of the professorial villa soon turns out to be tedious; Yvonne (literally) shuts the bedroom door before her husband; instead, she starts an affair with a banker who owns a fast automobile. Divorced, Ambrosius encounters his former wife in Paris, an actress with a second-rank variété theatre. Previously appreciating ambitious music, Yvonne now acts in tearful hits, her appearances being primarily meant to lure clients as she actually makes her living on prostitution. Yvonne had not appreciated Ambrosius's love for her, and was punished for that in the fiction's world: with no backing from her husband, she found herself at the bottom of the barrel. On the other hand, the reader has a good reason to suppose that Ambrosius's sentiment for Yvonne, who is portrayed as a woman incapable of 'true' love, was in fact an unwholesome fascination that made him blind to the 'healthy' type of eroticism represented by Helene, completely dissimilar to Yvonne's. Similarly to the other women appearing in the novel, Yvonne is used as part of a background against which the model of femininity impersonated by Helene positively stands out. At a closer glance, one finds that in spite of the main character being radically empowered, the model is quite similar to the image of womanliness which just a few years later became dominant in the Nazi propaganda and public life in Germany. By way of contrast, the figure of Yvonne Pastouri allows to show Helene as a woman whose character as well as body and sexuality are marked with positive - and, somewhat astonishingly, national - traits. One of the key threads in the novel is a springtime outing of a group of students. A pack of friends, Helene and Rainer among them, are making a boat trip out of town. They spend the day rowing; in the evening, at a nearby inn, they meet Professor Ambrosius and his wife, who arrange a knees-up on the spot. The highlight of the night is Harryman Samson, a black-skinned painter brought there all the way from Paris, who appears to be a jazz pianist as well. It was his glance, an exotic glance from the outside, that makes us aware what we are looking at, and helps name it: "A French woman, very - oh yes, very light, she! - dancing on the open palm ... But a German woman - heavy. Growing into earth. Like a grand tree. Just like this - voyez là-bas! Down out there, where his finger with a clear pointed nail on the top was pointing out, Helene was 
climbing up the scarp, Meier and Rainer following her. It was cold for her, so she stretched her arms in the warm and sunny air, and indeed looked a little bit like a tree stretching its boughs upwards, toward the sun". ${ }^{25}$ This is not the only description of Helene that emphasises her association with (the) earth and with nature. When seated at dusk on a seaside rock, Helene's body "looked as if it sprouted from the cliff's dark rocks". ${ }^{26}$ Yvonne Pastouri, her antithesis, is described in a completely different manner. Her body is artificial: posed, adorned with ornaments, arousing lust - a desire that is untrue, though: it is a game, one that is artificially kept up; an unhealthy object of excitement. The description of Yvonne posing for Harryman Samson is exemplary in this respect: "Yvonne Pastouri was not naked; she was more than naked, dressed in a shameless and exciting fashion. She had a pair of stockings on, and a skirt made of white fluffy tulle, with its upper edge below the hips. The whole remainder of her was naked, or rather, undressed. Between her small breasts is a necklace of matt black stones, coming down to her bosom; and this is all. Yvonne was seated on a black furry coat, her nipples very red, possibly highlighted with lipstick". ${ }^{27}$ The antithesis of Yvonne and Helene is complemented by the contradistinction between Frenchness and Germanness. Helene impersonates the German woman; Yvonne, her marriage to Ambrosius over, leaves for Paris. The catalyst of her decision is, notably, a black-skinned painter who has arrived from the capital city of France. Let us note that Harryman is described as a threatening, exotic 'Other': his smile is 'infernal', and he achieves satisfaction through arousing passions that damage the order and incite others to break the rules. The fact that Harryman came from Paris is not neutral in terms of significance: during the First World War black-skinned soldiers fought in the ranks of the French army, to which the German war propaganda responded with images of black half-humans, half-beasts kidnapping German women. The Samson thread might be read as alluding to those images. ${ }^{28}$ Also, the opposition of 'things German' versus 'things French' was a permanent item in the German nationalist discourse in the late nineteenth and early

${ }^{25}$ Ibidem, 48.

26 Ibidem, 176.

${ }^{27}$ Ibidem, 90.

${ }^{28}$ See Gisela Lebzelter, 'Die "Schwarze Schmach". Vorurteile - Propaganda Mythos', Geschichte und Gesellschaft, 1 (1985), 53-4. 
twentieth century. In Baum, it is evident how references to carnality and sexuality co-defined the difference between the national cultures in order to emphasise the advantages of Germanness.

Another typical means taken by Vicki Baum from the resource of populist propaganda is juxtaposing the sound and the sick. This antinomy is used in creating the above-discussed figure of Gudula Rapp, the archaeology student. Gudula is an unsettling character, for she ends up in failure, albeit basically she should by all means have succeeded: she studies passionately and with perseverance, and has enough strong will to overcome the difficulties; this means that the virtues she has are similar to those of Helene. What is peculiar about her, though, is an unrest. While Gudula also had had to prevail over her family's resistance in order to go to a university, she does not feel satisfaction because of having "got it all her own way"; unlike Helene, she mostly feels remorseful, particularly with every letter received from her family and testifying to poverty prevalent at home. Gudula is haunted by quandaries also when at work: working on her doctor's thesis, she unceasingly fights the arising doubts, and her desperate efforts produce incommensurable results. Gudula's emotional problems stem from her repressed homosexuality: "Poor Gudula, who is so bravely fighting against herself, every day and every night; who so deeply suppresses her perverse and unsound inclination. Her small stature is growing increasingly fleshless, her glance from behind the glasses more and more hysterical, her slim hands, as if made of yellowed ivory, increasingly trembling, a victorious fulfilment and inner balance more and more frequently escaping dodging her restless soul ...". ${ }^{29}$ The figure of Gudula Rapp stands for a whole bundle of stereotypes or negative concepts: an image of intellectual woman as a person with repressed sexuality or prone to perversion, an idea of woman as a hysteric, and of lesbian as a blocked individual, never reconciled with herself and/or uncreative. This character is, in parallel, a point of reference for the protagonist, one that enables to highlight the 'sound' sexuality of Helene by contrasting it with Gudula's 'unhealthy inclinations'. One more element of this configuration is the significance ascribed to maternity. Extramarital maternity brought about a breakthrough in Helene's life, becoming a source of vitality and strength to do hard work. For Gudula, "victorious fulfilment and inner balance" ensuing from sexuality and

${ }^{29}$ Baum, Helene, 99. 
maternity remain inaccessible, and thereby, in line with the novel's logic, she will never achieve success in her scholarly endeavours.

The concept of femininity impersonated by Helene combines empowerment with traditionalist and conservative elements, thus effectively proving to be utopian: it merged the ingredients that could make up a harmonious whole only within the confines of a novelistic experiment. Albeit a völkisch or nationalist vision of the world accommodated a strong, physically fit woman, ready to make sacrifices, disciplined and 'maternal' in one, the other aspects of the character of Helene would have been unwelcome after 1933, at the latest - her exposed career-related position and economic independence standing out among them. Despite the appearances, this dependence works also with the notion of maternity. True, just like the nationalist(ic) ideology had it, Vicki Baum attaches enormous significance to maternity, outright founding upon it the value of woman's existence, which she emphatically highlights by showing the failure of Gudula Rapp, a lesbian. Yet, the novel is about maternity by genuine choice, a maternity that is self-dependent, non-rationed and free of (state) control - something unthinkable-of in the Nazi worldview: suffice it to recall the state orders for multiple mothers, or the racial concepts behind the Lebensborn, or the procedure of contracting 'racially valuable' marriages by members of the SS. ${ }^{30}$ I should therefore think that identifying the figure of Helene as a form of accession to nationalism, or as precursory to the Nazi image of woman, would be illegitimate. ${ }^{31}$ The figure of Helene is, in turn, doubtlessly an attempt at merging the conservative model

${ }^{30}$ See, for instance, the study by Isabel Heinemann, Rasse, Siedlung, deutsches Blut. Das Rasse- und Siedlungshauptamt der SS und die rassenpolitische Neuordnung Europas (Göttingen, 2003), based on meticulous archive-supported research.

${ }^{31}$ Annette Kliewer shows that the images and concepts of maternity shown in the women authors' texts might have been precursory to the Nazi policies. She remarks that the question calls for nuanced analysis, and no generalising reply can be given to it. With respect to Vicki Baum, it has to be pointed out that female nationalist authors such as, e.g., Elisabeth Wentscher or Paula Schlier saw the experience of maternity as one allowing to 'deepen' the literary activity; see Annette Kliewer, Geistesfrucht und Leibesfrucht. Mütterlichkeit und "weibliches Schreiben” im Kontext der ersten bürgerlichen Frauenbewegung (Pfaffenweiler, 1993), 277-85. A similar motif appears in Baum's novel: Helene's biological maternity helps deepen and reinforce her passion as a research scholar. The concept of positive interrelation between maternity and creative work was not new to the interwar authors (to mention Helene Stöcker's studies from the early years of the twentieth century); cf. ibidem, 32-4. 
of femininity with the achievements of emancipation and the effects of the changes taking place in the modern life. The popularity of the novel makes legitimate the presumption that the author successfully combined and juxtaposed the elements which her (female) readers found the most attractive. However, the developments occurring after 1933, just three years after stud. chem. Helene Willfüer was published, demonstrated that the empowered and educated German mother was in fact a hybrid being, capable of living only under the hothouse conditions of literature.

II

MARA, A DISAPPOINTED STUDENT, AND HER PROFESSOR

Maternity was an essential experience also for the protagonist of Grete von Urbanitzky's novel Eine Frau erlebt die Welt. Grete von Urbanitzky (1891-1974) was less popular than Baum among the reading public in the interwar period; and this has remained so today. Compared to Baum's prose output, Urbanitzky's output is of a different nature. Her books are sated with references to the theories that fascinated this author: an explicit example being her polemical, yet very intensive, reception of Otto Weiniger's Sex and Character, which is evident in several novels by the Austrian authoress. Urbanitzky arouses interest among literary scholars today primarily as the author of the major literary text on lesbian matters penned during the Interbellum - the novel Der wilde Garten (The Wild Garden, 1927). Urbanitzky actively participated in Viennese (and Austrian) literary life, was active as a journalist and editor, founder of Vienna-based PEN-Club section. She worked as manager of the press office of the Viennese Volksoper, and ran a sort of agency that intermediated between the authors of texts and the press. Her novels were willingly reviewed, in most cases positively; they enjoyed some popularity among readers as well. The writer's outlook and political attitude are not easy to unambiguously define; Urbanitzky tended to oscillate between the extreme ends of the political spectrum, which is reflected in her literary texts as well as journalistic activity. On the one hand, she made contributions to leftist-liberal and even Marxist press; on the other, she declared nationalistic views, and quickly opted for the Nazi regime. In May 1933 she essentially contributed to a conflict within the Viennese PEN-Club section she had set up, which surfaced at the organisation's 
international congress in Dubrovnik: she refused to join the assembly's resolution condemning the burning of books by the Nazis, which led to a fracture within the Viennese section. Urbanitzky emigrated afterwards to Germany, where she lived for a short while: in 1936 she moved to Paris due to increasing reluctance of the Nazi authorities towards her works as well as private live (a lesbian, she was moreover described in an anonymous letter to the Gestapo as a person of Jewish descent; the latter has not been confirmed by the research on her biography). After a series of confiscations and bans imposed on her specified books, Urbanitzky was put in 1941 on the index of banned authors. After the war, she spoke of herself as a victim of Nazism - a view that has never been accepted by the public opinion. ${ }^{32}$

Eine Frau erlebt die Welt reflects its author's hard-to-define ideological attitude: the image of empowered protagonist is accompanied, for instance, by expressions of admiration of the fascist order in Italy. The main character, named Mara, is the common element with the Vicki Baum novel. There is a number of similarities between Mara and Helene - one being the youth-age rebellion which propels their idea to study in spite of their immediate environment's opinion. When a six-year-old girl, Mara admires the figures of great leaders William Tell, Julius Caesar, Napoleon; she wants to be like them, and command an army. She suffers severely because of the response of her elders who make her aware that such daydreams cannot come true for a girl. Somewhat later on, Mara alleviates her attitude and turns toward feminine models, which she however subjects to a peculiar selection: "Was Judith not magnificent, so different from the examples of deep submissiveness that sister Elisabeth continually put forth for me to consider? How brave she was as she walked beyond the town's gates, to the Assyrian commander's camp! ... And, as she later on came back late in the night, and the men illuminated her face and got scared at the unbelievable flare of her beauty, when she lifted the killed man's head high up to the light! Esther was different, too. Oh how wise she was! Can I really not wish for myself to be one such, to

32 The biographical details are quoted after Ursula Huber, 'Grete von Urbanitzky - ungeliebte Parteigängerin der Nationalsozialisten', L'Homme Z.F.G., iv, 1 (1993), 74-88; the article is based on an unpublished dissertation on Urbanitzky: eadem, "Frau und doch kein Weib". Zu Grete von Urbanitzky. Monographische Studie zur Frauenliteratur in der österreichischen Zwischenkriegszeit und im Nationalsozialismus (Vienna, 1990). 
become like those women were?". ${ }^{33}$ Initially, Mara's will to be unique and attain great purposes gets fulfilled in her intellectual ambitions. The admonitions of sister Elisabeth, who told her that "One should quash the haughtiness of thinking inside oneself ... since it comes from Satan", ${ }^{34}$ could not withhold her. Mara would like to serve God - religion is an important thread in this novel - not in humility, though, but through great deeds. With this intention in mind, she commences her studies at the university of Zurich, where she very soon distinguishes herself with her abilities and industriousness, becoming an assistant to Professor Wernheim, an astrophysicist. She perceives her assistantship as a mission, and service offered to the great man and his work; making use of the religious universe of ideas, which is close to her, she compares her function of assistant with the role of John the Baptist. In spite of rebelling against humbleness instilled in her by the nuns, Mara seems to be completely satisfied with her supporting role. Moreover, she much appreciates the supraindividual quality of science: "The laws of science express matter. Individuality ends at the scientist's workshop. 'I' submits itself". ${ }^{35}$ Incidentally, this conviction is not at odds with her specific cult for Professor Wernheim. The astrophysicist, using some at first incomprehensible instruments in his observatory cut off from everyday reality, appears to Mara as a contemporary wizard, "master of esoteric things". ${ }^{36}$ Mara is exhilarated by his zeal; Wernheim is described as a man who "was very enthusiastic about his discipline like a young adept". ${ }^{37}$ His focus on investigating the regularities governing the Space, and expanding the resource of knowledge, seem at first the utmost goal to her. "This was the road to the utmost knowledge, to cognising the meaning and purpose in life". ${ }^{38}$ Wernheim was, in turn, enchanted by the mathematical aptitudes of the woman student, and by her fervour and assiduity. Their collaboration, however, does not immediately go seamlessly; at the beginning, it is hindered by aspects of sexuality.

Mara's approach to the issue of sexuality is completely different than the one represented by the character portrayed by Vicki Baum.

33 Urbanitzky, Eine Frau (1937), 23.

${ }^{34}$ Ibidem, 31.

${ }^{35}$ Ibidem, 64.

${ }^{36}$ Ibidem, 72.

37 Ibidem, 105.

38 Ibidem, 104. 
As we can remember, Helene got pregnant, as a specific situation led her to a moment of lapse. In Helene's modern, ordered and rational world, the spontaneous knees-up at a picnic appears as an excess, almost a bacchanalia. In Urbanitzky's novel, sexuality is opposed against rationality - with a completely different result, though. Mara experiences the sex drive as a restriction on her freedom, a burdensomeness and obstacle to be removed if she is willing to follow the path set by will and intellect. "Never lose yourself. That's what it was about. This very thing. ... Why am I scared by what makes me seek such kisses? I am free, there's no-one to command me". ${ }^{39}$ To discharge the sexual tension, Mara develops brief relationships with men, avoiding emotional bonds: "The thing I know is that it needs being done, if you don't want to perish because of it, or incessantly think about it". ${ }^{40}$ At the same time, she takes conscientious effort to separate the world where she is a student from 'that other one' in which she is a sexual being. ${ }^{41}$ As it appears, this is a right thing to do, for the sexual drive determines her relationships with men who can perceive her as a student or as a lover, never able to combine the two aspects - as is quite clear in her acquaintance with Professor Wernheim. The beginning of their cooperation is dramatic. During Mara's first visit at the observatory, Wernheim yields himself to the drive. When he passes a coat to the girl as she leaves, an incident happens: "It was, merely, a moment. He rampantly pressed her towards him. She did not defend herself, did she. He could feel her mouth. He could feel her firm breasts under a thin blouse, when he was pressing Mara against himself. He forgot about the whole world. With brutality of wild desire, he tried to push her toward the bed ... 'You must be saved from the studying. You are destined to something else in this world ..." 42 Mara is shocked with Wernheim's behaviour; she breaks free and flees. Wernheim soon starts regretting and is ashamed of his ungovernableness; he fears he has squandered the opportunity to work together with Mara. Finally, however, the student resolves to be his assistant, and makes up her mind on behalf of him and herself: "We will both forget about it. There are some greater issues

\footnotetext{
${ }^{39}$ Ibidem, 69.

40 Ibidem, 89.

${ }^{41}$ Ibidem, 82.

42 Ibidem, 80.
} 
at stake". ${ }^{43}$ This is, most clearly, Professor Wernheim's own opinion as well, for no other incident occurs, and collaboration between the two goes harmoniously ever since.

Mara takes effort to place sexuality in a subordinate position. She does not suppress it, though (contrary to Helene), but tries to canalise it instead. She settles her relationships with men, subjecting them to her personal plans. She is willing to bring up her child on her own, perceiving marriage as contrary to her intentions; and, she responds almost with euphoria when she learns she is pregnant. She makes fantastic plans to deliver a blond-haired boy (herself being swarthy and black-haired), and to spend the whole life together with him - not only living but also working together: "It would be just magnificent, certainly, when she turns grey. She would be a docent or professor by then, an associate of great scholars at work. After work, she would not have to go back to an empty cold house. He would be there, after all: her big, fair-haired boy, who would by then be studying at a university. Would he like to be an astrophysicist as well? This would naturally be the best choice. She could then experience the most superb thing: working together with him". ${ }^{44}$ In these fancies she transfers to her future child (not knowing the baby's sex yet) the emotional needs not to be satisfied by a man. Only a son could give her closeness without sexuality; the other men see in her a sexual being, which obscures to them her intellectual and creative potential. ${ }^{45}$ Mara's fancies would never come true, though. Initially, everything goes as scheduled, a baby boy comes into the world. Unlike Helene, Mara avoids a scandal, discontinues her studies for one term and returns to her hometown, the Croatian locality of Gruda, to deliver the baby there. She leaves him there with her own former baby-minder and goes back to Zurich, planning to take the boy with her once she completes her studies.

These intents are challenged by a secret organisation, set up, funded and run by a mysterious English millionaire, a certain, Evans. The organisation has always taken interest in Mara's fortunes, once providing for her upbringing and now radically intervening in her life: the

43 Ibidem, 95.

${ }^{44}$ Ibidem, 107-8.

45 This is most emphatically shown in a section of the novel I do not discuss herein, as it describes Mara's history after she left the job with the observatory. Mara is a concert organist then and has a husband who finds it awkward that his wife approaches music so ponderously, instead of making him central to her existence. 
boy is kidnapped and given up for adoption, without her knowing it. Mr. Evans's organisation is carrying out a social experiment: with use of capital and science, they are endeavouring to build a society of happy people. They discreetly control the fates of people put in difficult positions, offering assistance at the appropriate moment, camouflaged as a twist of fate or coincidence. But this is not all: the organisation has a laboratory set up on their private island, where researchers are working, among other things, on how to influence human character in order to make people akin to one another, which would in turn allow to find a "norm of happiness for all the specimens" of humankind. ${ }^{46}$ The British millionaire's care for Mara is quite peculiar. Evans extends special care for her, as Mara is a foster-sister of his little boy who had died a tragic death. The aid supplied to Mara is meant to provide her with a wealth of experiences, enabling a possibly full development of her outstanding capacities and achievement of success in any field she might choose to pursue. Owing to the people she encounters at appropriate moments, Mara is to find her own way: thus, the novel refers to the history of Goethe's Wilhelm Meister and becomes part of the Bildungsroman tradition. For a long time, Mara seems not to notice, or is not willing to notice, the interventions of a mysterious benefactor; she thoughtlessly takes advantage of the funds she receives - possibly because her purpose coincides with that of Mr. Evans who expects Mara to accomplish great things. However, when it comes to that, the limitations of the philanthropist millionaire's social experiment become apparent; he usurps a demiurgic role and perceives God as his rival, and expects to win over Providence. Evans assumes that bringing up the child will hinder the realisation of Mara's potential. The thing is, it is the severed contact with her son that largely contributes to Mara's loss of any sense of her doings, and she starts doubting in the value of scientific work. Since her boy disappeared, Mara increasingly loses the sense of self-efficacy and belief in free will.

Disbelief in science is one of two severe disappointments in Mara's life. The other one is her scepticism about art: this musically talented woman becomes at one point a professional organist, giving concerts all around Europe - up to the point the feeling of nonsense inclines her to quit this career as well. She initially approaches music and science with a great enthusiasm, and proves successful in both areas.

${ }^{46}$ Urbanitzky, Eine Frau (1937), 560. 
On her first visit to the observatory, Mara feels like she were "walking into a sanctuary". ${ }^{47}$ Not only does she believe at first that science is her mission in life, but she is fascinated with the expert knowledge related to astrophysics - measurement instruments, new theories, methods of calculation. Her ambition is to master this knowledge and the related skills. However, disappointment becomes increasingly apparent and the coincidence of two disasters, personal and worldwide, is the moment that marks Mara's conclusive disappointment with scientific work. At first, the observatory offered a refuge allowing to cut herself off from personal sufferings and wartime horror: "The work done at Wernheim's was desensitising. It seemed that also the Professor abandoned himself to his research even more passionately than before; it sometimes seemed to the scholar and his assistant that they have scuttled from the Earth to another planet". ${ }^{48}$ Such escapism proves insufficient with time, though. ${ }^{49}$ Mara finally finds that she "cannot have happiness within the circle of science, which has elevated matter to the rank of God". ${ }^{50}$ Mara's disbelief and disappointment focuses within the rhetorical question: "What is the sense of science if knowledge is the only thing it seeks ... if it doesn't intend to be helpful in bearing our temporality, in a deeper understanding of His [God's - J.G.] designs". ${ }^{51}$ She remarks, however, that a recipe for happiness of humankind is not what she expects from science (thus, unaware yet of Evans's project whose purpose is to make every human being happy through science, she distances herself from it): "It was a stupid question. For, is it about happiness really? There should be something to place a bet on: marching forward and ascending, the very essential thing. What Wernheim investigated - can this point the way for people?"52 Professor Wernheim appears to her ever since not as a master but as a blind man: "She saw him, glad of himself and free of any doubt, striding along the path leading to a void". ${ }^{53}$ This disappointment causes Mara to turn her back on science. Thomas Aquinas's Compendium theologiae comes as a help in her disbelief:

\footnotetext{
47 Ibidem, 72.

48 Ibidem, 228.

49 Ibidem, 255.

${ }^{50}$ Ibidem, 204.

${ }^{51}$ Ibidem, 276.

52 Ibidem, 153-4.

53 Ibidem, 205.
} 
what she catches up from this book is a differentiation between actions ensuing from 'necessity of nature' or 'necessity of matter' and 'voluntary' actions, those which are initiated by 'the intellect and will' (chap. 96). Astrophysics, and science in general, belongs in Mara's view to the area of 'necessity of nature' and investigates such 'necessary' proprieties of matter. In such limited scope, science does fulfil its function, yet Mara's ultimate goal would be to "find her own way to the land of freedom", ${ }^{4}$ governed by will and intellect. The road does not lead through science, though. This is confirmed by the later history of Professor Wernheim, an astrophysicist who gradually turns into an astrologist; he tries to persuade Mara into his new passion - into the belief that it is constellations of stars and planets that determine human fortunes. This metamorphosis might have been inspired by (yes, exactly) the Compendium, where Thomas considers the impact of 'celestial bodies' (and human fates purportedly inscribed, as it were, in them) on human, and comes to the conclusion that: “... thus heavenly movement has some indirect influence on the activity of the human intellect and will, so far as the will may be inclined this way or that by the passions. Nevertheless, since the will is not subject to the passions in such a way as necessarily to follow their enticement, but on the contrary has it in its power to repress passion by the judgment of reason, the human will is not subject to impressions emanating from heavenly bodies. It retains free judgment either to follow or to resist their attractions, as may seem to it expedient" (chap. 128). ${ }^{55}$ This concept is one of the novel's pillars; Professor Wernheim, astrophysicist, turns into a representative of 'natural' necessity from which it follows that stars and planets influence people. His evolution from astrophysics to astrology is, paradoxically, not a great change but merely yet another step on the way to examining the 'necessity of matter', an act of drawing the conclusions, in a way, from the limitations of science which will never penetrate into the sphere of will- and intellect-driven 'freedom'. This is confirmed by the novel's reality. On the one hand, the warning horoscopes Wernheim

${ }^{54}$ Ibidem, 280.

${ }^{55}$ Quoted after Compendium of Theology by St. Thomas Aquinas, transl. by Cyril Vollert, S.F., S.T.D. (St. Louis and London, 1952 [4th imp.; 1st ed. 1947]); cf. https:// archive.org/stream/CompendiumOfTheologyAquinasSt.Thomas3506/

Compendium+of+Theology+-+Aquinas,+St.+Thomas_3506_djvu.txt [Accessed: 20 July 2018]. 
sends to Mara appear correct: what they forecast becomes fulfilled. On the other hand, Mara manages to overcome the influence of stars, at least in the novel's original version. The peril foreseen for her by the stars consists in her encounter with her once-lost son as an adult man. Neither of the two knows who they are to each other, and the meeting ends with an incestuous affair. ${ }^{56}$ When Mara gets to know who the young Englishman is, she decides to disappear. The reader may suppose that she has committed suicide.

In summing up Mara's scholarly adventure, the reader comes to some head-spinning conclusions. Albeit science is a tool useful in cognising the nature's governing principles, such purely cognitive function is not what science should stop at: astrophysics is criticised as a domain that nowise improves the living conditions of humans or the functioning of society; nor has it a metaphysical quality as it does not make God any closer to man. What is more, the power of mind or intellect and human free will belong to the divine sphere, which is and remains inaccessible to science. Although using devices, mathematical calculations and scientific methodology, astrophysics essentially remains at the same level as astrology; both, each in its own way, describe the determinism governing the world, and thus the novel equalises scientific and magical thinking. Such convictions are advocated, let us add, by the emancipated protagonist, who at some point leaves for Italy and admires the local fascist regime as a movement that unifies everybody while letting "every man live his life peacefully, according to his own individual laws" ${ }^{57}$ : really a tour de force in terms of ideological setting. The ideological confusion becomes even deeper owing to the fact that the author has altered the novel's conclusion: while the second (1934) and subsequent editions end with the protagonist's presumed suicide, the first edition (1931) contained one more chapter, which was then deleted. It described a vision of a future, possibly chronologically identifiable as the 1950s decade. It is a world where communism has won, class and gender differences levelled. Women have come to political power, and we hear about "women-presidents ... of the republics and a women's clique that has taken over the major positions in all the

${ }^{56}$ In the altered version, no physical relationship develops as Mara resists his advance, for reasons unclear to herself.

57 Urbanitzky, Eine Frau (1937), 549. 
offices". ${ }^{58}$ It is a world of affluence; also, science has made a stunning progress, capable now of extending humans' youth by dozens of years. In this world, equality has assumed the form of excessive normativisation whilst individuality has been evicted (there are no criminals and no individuals of genius; there is a single philosophy of life and a single obligatory set of political opinions, whereas art is collective) ${ }^{59}$ The omnipresent uniformity ensures wealth and prosperity while denying freedom. This is what Mara wants to remedy. Shown in this future world as a founder of a Christianity-based religion, she strives for eliminating the antagonisms such as the difference between the sexes, in a way so as to avoid standardisation: it is not about erasing contradictions but about harmonising them. This is meant to be brought about with use of a religion of love and life, rooted in Christianity and strictly following the evangelical patterns.

The altered conclusion creates a dissonance in the plot: Mara's adolescent rebellion, the prognostication of 'great deeds' she is ready to do, which in the first version finds fulfilment in her role as the founder of a new religion, in the second version get blurred, as it were, in vacuum; the open-ended conclusion renders them suspended. The original version has Mara's life go on; the novel ends with her son's words, proclaiming her as a matriarchal prophetess. ${ }^{60}$ Mara commits no suicide and overcomes her sense of guilt due to the incestuous act; she thus countermines the intents of 'the stars', preventing submission to the fortune imposed on her by coincidence, and thereby soars above the sphere of 'natural necessity' described in the Compendium theologiae. Mara as the founder of a new religion is also an element in the dispute between Urbanitzky and Weininger, who considered the attitude of religion's founder to be the utmost degree of genius, inaccessible to woman. To his mind, it is a genius that thoroughly experiences the old regime in order to overcome it inside himself and establish a new one instead. ${ }^{61}$

In the novel's altered version, the protagonist cannot resist her fate unless going self-destroyed; hence, forces of nature, beyond reason,

58 Urbanitzky, Eine Frau (1931), 584.

59 Ibidem, 585.

${ }^{60}$ Mara's son thus speaks of her: "Tell her ... that I love her ... The hope for the future rests in that it is a woman who makes us her sons - us the confessors, which is who we are"; ibidem, 599.

${ }^{61}$ Otto Weininger, Geschlecht und Charakter (Wien, 1908), 446 ff. 
prevail. Professor Wernheim's belief in inevitability of the fortune written in the stars appears to be right - as is his decision to abandon astrophysics and devote himself to astrology. In this view, a tangle of criticism of culture and irrationalism appears at this point, which can be recognised as literarily processed concepts revolving in the orbits of racism and Völkism. ${ }^{62}$ As is otherwise known, Urbanitzky took interest in writings of this sort. ${ }^{63}$ Her novel can be read as an attempt to include women's empowerment in the nationalistic-populist discourse. A similar tendency is identifiable, in my view, in Vicki Baum: Helene is a portrayal of emancipated woman, independent of men (including financially), but at the same time archetypically German and maternal. In the second, altered version of her novel, Urbanitzky seemingly does a similar thing. Mara, emancipated, finally ends up in a failure. But this failure can be explained: it did not fall to her lot to achieve fulfilment as a mother and if the child had not been taken away from her, no incestuous act would have occurred, for the bond between her and her son would have been expressed in a different, socially acceptable way.

\section{III}

\section{CONCLUSION: INSTANCES OF UNDER-CRITICAL CRITICISM?}

A studying woman's doubting about scientific work is not a unique motif in novels on female students. Science is not shown in them as a promised land at all. Romana Weiershausen discerns a scepticism relating to the discipline being studied in prose works from as early as the late nineteenth/early twentieth century, giving an example of a fictitious woman student of law who ascertains that the legal system is unfair and finally refuses to partake in its functioning. ${ }^{64}$ The antithesis 'science' versus 'life' is typical when it comes to criticising

62 This issue is addressed by, for example, Nicholas Goodrick-Clarke, The Occult Roots of Nazism: The Ariosophists of Austria and Germany, 1890-1935 (Wellingborough, 1985), where the associations are discussed between the völkisch ideology and racism, on the one hand, and theosophy and astrology, on the other, with their influence on Nazism.

${ }^{63}$ She was fascinated, among other things, by the racist ideas of Arthur Trebitsch. Her 1920 novel Das andere Blut is a literary transposition of Trebitsch's Geist und Judentum (1919); cf. Huber, Ungewollte Parteigängerin, 77.

${ }^{64}$ Weiershausen, Wissenschaft und Weiblichkeit, 61-124. 
science; in Urbanitzky's novel, science is not capable of rising to the challenge of life. Vicki Baum resorts, in turn, to a new element commercialisation of science. Studying chemistry starts to make any sense thanks to the chemical industry, which turns the attainments of chemistry into socially useful products. There is a 'critical potential' of these novels in the scepticism toward science they describe: female students seem to detect the flaws in the system to which they have finally been admitted. This criticism is restricted, as a matter of fact: it is muffled mainly due to the fact that the protagonists do not perceive the hardships they come across during their studies and scientific work as ensuing from sex-related discrimination. Although the position Helene initially holds is no better than that of Gudula Rapp, whereas her male mate is offered an excellent job with the chemical industry very soon after graduation, Baum's novel tries to convince us that success is determined by one's personal values whereas gender is a hindrance to be overcome with a great deal of hard work.

Mara's history would likewise basically devoid of a systemic afterthought on the situation of women; instead, it is this protagonist's uniqueness that emphasis is placed on. Mara was distinct amidst her peers already when a girl: when they dream of a first love, her plan for her life is different. Also in her relationship with Professor Wernheim, Mara's behaviour is untypical; this is basically reflected in the fact that, in spite of the repeated insinuations of those around her, she perceives him as an intellectual preceptor and avoids inciting love for her in him. On the contrary - it is Wernheim who is driven, for a short while, by the impulse of sexual drive. Much like Helene, Mara is a lonely individualist.

I put an emphasis on the attenuation of 'critical potential' in these novels, for this is the reason why Helene and Mara, albeit both typically empowered protagonists, have been excluded from the emancipation discourse. In Vicki Baum, Helene is the only woman who attains autonomy. The novel by Urbanitzky basically heads toward a conservative cultural criticism, which extends to science. The latter proves incapable of setting the reality in an order, or build a stable system: the altered version of the novel's conclusion shows primacy of the irrational element over the mind, the forces of nature over human will. Even the futuristic communist dystopia, removed by the author after the first edition, was meant to show the individual accomplishment of a single unique woman - a genius (female) founder of a religion, 
to follow Otto Weininger's phrase. ${ }^{65}$ If a 'critical potential', the way Weiershausen comprehends it, is to be sought in these novels, it might potentially be identified in the image of maternity, if anywhere. While maternity is shown as an indispensable condition for adding sense to woman's life - which, in any case, narrows down the perspective and is strongly associated with the Nazi propaganda - maternity is, clearly, what Helene and Mara appropriate for themselves, in a sense. Both have a child delivered outside marriage, so maternity does not contribute to their enhanced social capital. Their maternity is excluded from the social system, they both have a child born for themselves. Mara's possessiveness toward her son turns downright pathological (vide her daydream about living and working together with her adult son). Helene, a strong-willed and physically fit 'German woman', forms a self-reliant dyad with her son, who admires her; entering into an amorous relationship with Helene, Ambrosius creates a relation with her son as well.

Such a concept of maternity, along with the protagonists' independence, their confidence and the successes they have in the domains of their choice were, doubtlessly, the elements which could have gained recognition in the eyes of female readers who sought in literature powerful, independence-inspiring female characters. This particular aspect of the novels under discussion is nowise abated by the aboveremarked associations with ideologies having not much to do with emancipation. The literary character of female student, an educated woman pursuing scholarly activity, enables to present a less restricted and, perhaps, more attractive version of a woman's biography compared to the one envisioned in the traditional femininity discourse.

trans. Tristan Korecki

${ }^{65}$ Urbanitzky's close terms with the current described as conservative criticism of culture is confirmed by her apology of rough nature, the urban life, utterly imbued with falsehood, contrasted against a 'true' simple life in a fishermen's settlement somewhere in Italy. The aforementioned utopian vision of Italian fascism as an apolitical social movement which frees man from particularisms and unifies freely living individuals, is a substantial guideline. 


\section{SELECTED BIBLIOGRAPHY}

Bertschik Julia, "Ihr Name war ein Begriff wie Melissengeist oder Leibnizkekse”. Vicki Baum und der Berliner Ullstein-Verlag', in Walther Fähnders and Helga Karrenbrock (eds.), Autorinnen der Weimarer Republik (Bielefeld, 2003), 119-35. Bertschik Julia, 'Vicki Baum: Gelebter und inszenierter Typ der "Neuen Frau"', in Waltraud Wende (ed.), Nora verläßt ihr Puppenheim. Autorinnen des zwanzigsten Jahrhunderts und ihr Beitrag zur ästhetischen Innovation (Stuttgart and Weimar, 2000), 66-87.

Bock Petra, 'Zwischen den Zeiten - Neue Frauen und die Weimarer Republik', in eadem/Katja Koblitz (eds.), Neue Frauen zwischen den Zeiten (Berlin, 1955), 15-37.

Huber Ursula, 'Grete von Urbanitzky - ungeliebte Parteigängerin der Nationalsozialisten', L'Homme Z.F.G., iv, 1 (1993), 74-88.

Huber Ursula, 'Die Frau als "Künstlerin”. "Klugrednerei?” Fragen der weiblichen Identität und Macht in einigen Romanen Grete von Urbanitzkys', Zeitgeschichte, xvi, 11/12 (1989), 387-95.

Kliewer Annette, Geistesfrucht und Leibesfrucht. Mütterlichkeit und "weibliches Schreiben" im Kontext der ersten bürgerlichen Frauenbewegung (Pfaffenweiler, 1993).

Nottelmann Nicole, Strategien des Erfolgs. Narratologische Analysen exemplarischer Romane Vicki Baums (Würzburg, 2002).

Nottelmann Nicole, Die Karrieren der Vicki Baum. Eine Biographie (Köln, 2007).

Weiershausen Romana, Wissenschaft und Weiblichkeit. Die Studentin in der Literatur der Jahrhundertwende (Göttingen, 2004).

Weininger Otto, Geschlecht und Charakter (Wien, 1908).

Justyna Górny - 19th- and 20th-century German speaking area literature; assistant professor at the Institute of German Studies, University of Warsaw;

e-mail: jgorny@uw.edu.pl 